\title{
MANFAAT BIOGAS SEBAGAI BAHAN BAKAR ALTERNATIF BAGI RUMAH TANGGA
}

\author{
Ida Mustikawati \\ Progam Studi Ilmu Administrasi Negara \\ STIA Pembangunan Jember \\ *Email: idamustikawati@gmail.com
}

\begin{abstract}
ABSTRAK
Biogas adalah gas yang mudah terbakar dan dihasilkan oleh aktifitas anaerob atau fermentasi dari bahan-bahan organik termasuk diantaranya; kotoran manusia dan hewan, limbah domestik (rumah tangga), sampah biodegradable atau setiap limbah organik yang biodegradable dalam kondisi anaerobik. Kandungan utama dalam biogas adalah metana dan karbon dioksida. sistem biogas sederhana. Disamping itu di daerah yang banyak industri pemrosesan makanan antara lain tahu, tempe, ikan pindang atau brem bisa menyatukan saluran limbahnya ke dalam system biogas. Sehingga limbah industri tersebut tidak mencemari lingkungan disekitarnya. Hal ini memungkinkan karena limbah industri tersebut diatas berasal dari bahan organik yang homogen. Jenis bahan organik yang diproses sangat mempengaruhi produktifitas sistem biogas disamping parameter-parameter lain seperti tempratur digester, $\mathrm{pH}$, tekanan dan kelembaban udara. Salah

satu cara menentuka bahan organik yang sesuai untuk menjadi bahan masukan sistem Biogas adalah dengan mengetahui perbandingan Karbon (C) dan Nitrogen $(\mathrm{N})$ atau disebut rasio $\mathrm{C} / \mathrm{N}$. Beberapa percobaan yang telah dilakukan oleh ISAT menunjukkan bahwa aktifitas metabolisme dari bakteri methanogenik akan optimal pada nilai rasio $\mathrm{C} / \mathrm{N}$ sekitar 8-20.

Biogas yang dihasilkan oleh aktifitas anaerobik sangat populer digunakan untuk mengolah limbah biodegradable karena bahan bakar dapat dihasilkan sambil menghancurkan bakteri patogen dan sekaligus mengurangi volume limbah buangan. Metana dalam biogas, bila terbakar akan relatif lebih bersih daripada batu bara, dan menghasilkan energi yang lebih besar dengan emisi karbon dioksida yang lebih sedikit.

Kata kunci : Biogas, bahan, bakar
\end{abstract}




\section{A. Analisis Situasi}

Sumber bahan baku biogas tersedia secara melimpah dan belum banyak dimanfaatkan secara maksimal. Pemanfaatan biogas di Indonesia sebagai energy alternative sangat memungkinkan untuk di terapkan di masyarakat terlebih seiring dengan makin mahalnya harga bahan bakar minyak dan kadang-kadang langka keberadaannya potensi biomasa seperti kayu dari kegiatan industri pengolahan hutan, pertanian dan perkebunan lebih sulit penggunaannya sebagai bahan dasar biogas dibandingkan limbah kotoran ternak seperti kuda. sapi, kerbau, dan domba. Karena lebih lama waktu yang dibutuhkan untuk proses hidrolisis.

Di Indonesia, pemanfaatan Biogas masih terbatas pada bahan bakar kompor untuk memasak. Pemanfaatan Biogas untuk kebutuhan Rumah Tangga ini, beberapa penduduk di Indonesia sudah mampu membuat reaktor Biogas sendiri dengan skala kecil. Reaktor Biogas untuk skala kecil

umumnya dibuat dari plastic maupun dari drum.

Ketertarikan akan sumber energy Biogas akhir-akhir ini meningkat. Hal ini didasarkan pada fakta bahwa cadangan sumber energi fosil semakin berkurang. Salah satu buktinya adalah adanya kebijakan pemerintah dalam konversi minyak tanah ke Gas (LPG).

Dengan fakta ini sebenarnya beberapa anggota masyarakat yangmempunyai potensi mengolah bahan organik menjadi Biogas dapat berperan serta lebih efektif. Manfaatnya adalah masyarakat dapat memperoleh enerji yang relative lebih murah dan lingkungannya juga lebih bersih, karena biogas dihasilkan dari kotoran sehingga beberapa masyarakat masih canggung untuk menggunakan Biogas khususnya untuk masak

Kandungan methane yang
cukup tinggi dalam Biogas dapat
menggantikan peran LPG dan Petrol
(bensin). Sebagaimana bentuk bahan
bakar yang Inin, selain dimanfaatkan
untuk memasak. Biogas dapat
dimanfaatkan juga senagai bahan
bakar untuk penerangan.

Kandungan methane yang

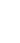


untuk proses pengeringan, untuk penghasil panas, untuk pembangkit listrik, atau bahkan untuk kendaraan bermotor.

Biogas sangat potensial sebagai sumber energy terbarukan karena kandungan methane $(\mathrm{CH} 4)$ yang tinggi dan nilai kalornya yang cukup tinggi. Methane $(\mathrm{CH} 4)$ yang memiliki satu karbon dalam setiap rantainya, dapat menghasilkan pembakaran yang lebih ramahlingkungan.

Pengelolaan limbah dilakukan agar dampak negatifnya dapat di minimalisir dan dampak yang menguntungkan dapat dimaksimalkan dengan tetap memperhatikan keseimbangan antara system produksi dengan lingkungan hidup. Manajemen penanganan limbah adalah sangat penting, antara lain karena (1) mencegah pencemaran di udara, tanah dan air, serta (2) mengekploitasi limbah sebagai bahan baku yang dapat mendatangkan keuntungan, kotoran ternak sapi. domba. kerbau, kuda, dan ayam dan limbah organic sisasisa tanaman adalah bahan yang baik untuk membuat biogas.
Menggunakan kotoran ternak saja, limbah tanaman saja atau campuran keduanya.

Keunggulan biogas lainnya adalah bahan bakar yang tidak menghasilkan asap dan sebagai pengganti bahan bakar minyak atau gas alam yang dihasilkan oleh suatu proses yang disebut pencemaran anaerob.

Industrialisasi dan urbanisasi dengan pelaksanaan pengembangan pertanian intensif menimbulkan pencemaran tanah pertanian oleh logam berat mengakibatkan produk pertanian pangan mengandung logam berat yang beresiko tinggi bagi kesehatan konsumen. Pemanfaatan limbah kotoran ternak menjadi sumber bahan baku biogas, diharapkan dapat menjadi salah satu solusi alternative pencegahan pencemaran logam berat pada tanah pertanian.

\section{B. Landasan Teori}

Biogas merupakan salah satu energy berupa gas yang dihasilkan dari bahan-bahan organic. Biogas merupakan salah energy terbarukan. Bahan-bahan yang digunakan untuk 
produksi biogas adalah bahan organic berupa limbah sayur, limbah rumah tangga, limbah buah, limbah rumah makan dan limbah kotoran ternak.

Biogas adalah gas yang di hasilkan dari proses penguraian bahan-bahan biologis/organic oleh organisme kecil pada kondisi tanpa oksigen, terutama bakteri metan. Suhu yang baik untuk proses fermentasi adalah 30 - 55 derajat Celcius dimana pada suhu tersebut mikroorganisme mampu merombak bahan-bahan organic secara optimal. Hasil perombakan bahan-bahan organic oleh bakteri adalah gas metan.

Biogas dapat dibakar seperti Elpiji. dalam skala besar biogas dapat digunakan sebagai pembangkit energy listrik, sehingga dapat dijadikan sumber energy alternative yang ramah lingkungan dan terbarukan.

Keuntungan penerapan

Biogas adalah masyarakat petani peternak dapat memasak dengan murah, bersih, ramah lingkungan mendorong kelestarian alam, meningkatkan produksi ternak, menghemat devisa Negara, dan mendukung perbaikan ekonomi masyarakat.

.Selain itu limbah hasil pembuatan biogas tidak dibuang begitu saja, tetapi dibuat pupuk yang kaya akan nutrisi.

Biogas adalah bahan bakar yang bersih karena tidak menghasilkan asap, sehingga alatalat dapur dapat tetap bersih selama di gunakan, dan berfungsi sebagai bahan bakar minyak atau gas alam pengganti yang unggul. Sebagian petani, peternak telah mulai membuat biogas untuk kebutuhan rumah tangganya, dengan menggunakan limbah tanaman dan kotoran ternak kandungan kedua bahan tersebut kaya sumber gas metana (CH4) yang memiliki daya bakar yang sangat baik. Dengan penggunaan biogas sederhana para petani ternak tidak perlu bekerja keras dan tetap dapat menghemat uang daerah jember adalah wilayah yang tidak terlalu dingin dari $15 \mathrm{C}$ ) dan tidak terlalu panas (suhu diatas 37 C) cukup bagus untuk memproduksi biogas, karena biogas 
lebih bagus diproduksi pada suhu 32370

$$
\text { Potensi pengembangan }
$$

biogas di Indonesin cukup besar dalam upaya memenuhi energy rumah tangga. Hal ini dikarenakan cukup banyaknya populasi hewan ternak seperti sapi, kerbau, dan kuda. Dari segi perhitungan ekonomis biogas dari kotoran ternak ini cukup menguntungkan sebagai pengganti bahan bakar minyak. Selain itu limbah biogas yang berupa lumpur dari effluent atau outlet digester biogas yang berwujud cairan ini merupakan pupuk organic cair (POC) yang sangat kaya akan unsurunsur yang dibutuhkan oleh tanaman

Lumpur dari outlet sebagai limbah biogas ini selanjutnya dapat diubah dalam bentuk butiran atau granule dengan cara dikeringkan dan ini tentunya juga memiliki nilai ekonomi yang tidak sedikit bilamana dijual sebagai pupuk organic granuel (POG).

\section{Identifikasi dan Perumusan Masalah}

Dari uraian tersebut di atas, maka identifikasi dan rumusan masalah adalah sebagai berikut "Bagaimanakah cara memberikan pemahaman tentang cara pembuatan manfaat dan dampak yang ditimbulkan dari penggunaan Biogas sebagai bahan bakar alternatif untuk Rumah Tangga.."

\section{Tujuan Kegiatan Kegiatan pengabdian pada masyarakat}

a.. Meningkatkan pemahaman tentang cara pembuatan dan manfaat biogas kepada masyarakat dan mengenal dampak positif penggunaan dan pemanfaatan Biogas untuk meringankan beban keuangan rumah tangga.

b. Meningkatkan peran masyarakat, para ahli dan instansi terkait untuk berpartisipasi melakukan edukasi melalui penyuluhan dan pelatihanpelatihan tentang cara pembuatan dan pemanfaatan biogas.

Manfaat Kegiatan Adapun manfaat yang dapat diperoleh setelah berlangsungnya kegiatan pelatihan ini adalah: 
A. Masyarakat memahami dan memperoleh pengetahuan cara pembuatan dan mantan yang ditimbulkan dari penggunaan biogas untuk kebutuhan meringankan beban ekonomi rumah tangga

b. Masyarakat memahami dampak positif yang ditimbulkan dari penggunaan bahan bakar biogas baik terhadap dampak lingkungan sosial, kesehatan dan ekonomi masyarakat

\section{E. Kerangka Pemecahan Masalah}

Berdasarkan kebutuhan di lapangan diperoleh gambaran bahwa masyarakat dusun Karangkongkap adalah salah satu dusun yang berada di desa Sruni yang keadaan ekonomi masyarakatnya kurang sejahtera di banding dusun-dusun yang lain di desa Sruni. Dengan kesedian masyarakat untuk beralih penggunan bahan bakar kayu, minyak atau Gas (LPG) ke Biogas akan banyak memberikan manfaat dan dampak yang positif terutama untuk meringankan beban keuangan rumah tangga selain manfaat-manfaat yang lain seperti untuk mengurangi polusi udara, mengurangi bau busuk dari kotoran ternak,kebersihan, kesehatan dan untuk dimanfaatkan sisa biogas untuk bahan pupuk pertanian dan manfaat lainnya. Oleh karena itu, karena pembuatan dan pemanfaatan biogas dapat memberikan manfaat dan dampak yang positif bagi lingkungan, sosial dan ekonomi masyarakat maka perlu terus dilakukan penyuluhan-penyuluhan dan pelatihan pelatihan oleh para ahli dan lembaga terkait untuk meningkatkan pemahaman melalui edukasi dan pelatihan secara efektif kepada masyarakat agar dapat mengatasi persoalan-persoalan yang terkait terutama ekonomi rumah tangga yang ada di dusun krangkong up dan dusun darungan desa Sruni Kecamatan Jenggawah Kabupaten Jember

\section{F. Khalayak Sasaran Kegiatan}

Penyuluhan ini diikuti oleh 20 orang yang terdiri dari ibu-ibu, pemuda, dan masyarakat lainnya dari desa Sruni khususnya masyarakat dusun Darungan dan Karangkongkap Kecamatan Jenggawah Kabupaten Jember dengan harapan kelompok masyarakat tersebut dapat mengaplikasikan cara pembuatan dan 
merasakan manfaat penggunaan Biogas sebagai bahan bakar alternatif yang dapat mengurangi atau meringankan beban ekonomi rumah tangga dan merasakan manfaatmanfaat serta dapat positif lainnya dari pemanfaatan penggunaan Biogas. Mudahan-mudahan pembuatan dan penggunaan Biogas mempunyai manfaat dan dampak yang sangat signifikan dan luas bagi masyarakat dan memperoleh apresiasi aparat desa yang kemudian di akomodir untuk dapat diformulasikan menjadi bagian dari program pemerintahan desa.

Metode Kegiatan Kegiatan ini diawali dengan survey lapangan terlebih dahulu permohonan jin kepada penanggung jawab wilayah mengumpulkan warga setempat untuk pelaksanaan kegiatan Sosialisasi.

\section{G. Evaluasi Kegiatan}

Evaluasi kegiatan ini dilakukan dengan pemantauan setelah pelaksanaan kegiatan penyuluhan ini, yaitu semakin terbuka masyarakat untuk menerima bahan bakar alternatif biogas yang dimana bahan baku pembuatannya dari kotoran torak yaitu map kambing dan ayam. Masyarakat cukup memahami betapa besar manfaat biogas untuk meringankan beban ekonomi rumah tangga.

Dalam hubungan ini seharusnya menjadi perhatian bersama bokan saja keluarga yang tergolong kurang mampu tetapi menjadi perhatian masyarakat dan para ahli di bidangnya dan instansi terkait pemerintah desa karena bahan bakar alternatif ini banyak sekali manfaat dan dampak positif yang ditimbulkan, baik dampaknya untuk kesehatan, udara, lingkungan sosial dan ekonomi masyarakat

\section{DAFTAR PUSTAKA}

Anonim. 2012. Pengertian Manfaat dan Komposisi Biogas. http://www.lebahndut.net/201 2/10/biogas-pengertianmanfaat-dan komposisibiogas.html. Akses: 14 Juni 2014.

Awing, et.al. 2013. "Studi Eksperimental Pengaruh 
Variasi Bahan Kering

Terhadap Produksi dan Nilai

Kalor Biogas Kotoran Sapi”.

Halaman 2. Harahap, F. M., 1978. Teknologi Gas Bio.

Pusat Teknologi

Pembangunan ITB, Bandung

Haryadi. 2006. Teknologi

Pengolahan Beras. Gajah

Mada University Press:

Yogyakarta

Hermawan, Beni dkk. 2007.

Pemanfaatan Sampah Organik sebagai Sumber Biogas

Untuk Mengatasi Krisis

Energi Dalam Negeri. Karya

Tulis Ilmiah Mahasiswa

Universitas Lampung. Bandar

Lampung.

Nurwantoro, Hakim. 2012. "Total

Bakteri Anaerob, Produksi

Gas dan Laju Produksi Gas

Bio-Digester dengan

Penambahan Sekam Padi

Pada Bahan Baku Feses Sapi

Potong”. Halaman 4.

Pambudi, N. A.,Pemanfaatan

Biogas sebagai Energi

Alternatif. http://www.dikti.org/?q=node/

99

Singh. 1977. Hal Berpengaruh Terhadap Biogas. http://repository.usu.ac.id/bitst ream/123456789/29673/3/Cha pter\%20II.pdf

Sridiyanti. 2014. Pengertian Energi Biogas.http://www.sridianti.c om/pengertianenergibiogas.html. Akses: 14 Juni 2014.

Sufyandi,A. 2001. Informasi Teknologi Tepat Guna Untuk Pedesaan Biogas. Bandung

Syamsuddin, T.R. 2005. Bahan Bakar Alternatif Asal Ternak. Sinar Tani, Edisi 21-27 Desember. No 3129.

Wahyuni, Sri. 2011. Menghasilkan Biogas Dari Aneka Limbah. PT Argro Media Pustaka: Jakarta. 